\title{
Mysterious overnight disappearance of mediastinal mass
}

\author{
Kundan Mishra, ${ }^{1}$ Giriraj Singh, ${ }^{2}$ Rajat Bahl, ${ }^{1}$ Uday Yanamandra (1) ${ }^{1}$
}

${ }^{1}$ Department of Hematology \& Stem Cell Transplant, Army Hospital Research and Referral New Delhi, Delhi, India ${ }^{2}$ Department of Radio-Diagnosis, Army Hospital Research and Referral, New Delhi, Delhi, India

\section{Correspondence to} Dr Uday Yanamandra; udayj2@gmail.com

Accepted 30 September 2020

Check for updates

(c) BMJ Publishing Group Limited 2020. No commercial re-use. See rights and permissions. Published by BMI.

To cite: Mishra K, Singh G, Bahl R, et al. BMJ Case Rep 2020;13:e238399. doi:10.1136/bcr-2020238399

\section{DESCRIPTION}

Preanalytical variables constitute a significant concern for reaching a diagnosis in day-to-day practice. While laboratory preanalytical errors are more commonly emphasised, preanalytical errors extend into many diagnostic areas. We present a case wherein a minor variation in the radiological technique led to a series of unnecessary investigations and wrong prognostication of the patient. This case highlights the necessity of a clinician to be aware of the fundamentals for various tests ordered routinely.

A 38-year-old man initially presented to a tertiary level hospital with gradually worsening B-symptoms, dyspnoea on exertion and abdominal fullness of 6 months duration. Clinical evaluation revealed tachycardia, tachypnoea and diminished breath sounds in both infrascapular areas with massive splenomegaly. The laboratory tests revealed bicytopenia with leucocytosis (haemoglobin $67 \mathrm{~g} / \mathrm{L}$, white blood cells $34 \times 10^{9} / \mathrm{L}$ and platelets $29 \times 10^{9} / \mathrm{L}$ ). Chest X-ray performed 1 week prior had suggested mild bilateral pleural effusion with cardiomegaly (figure 1). Because of the respiratory distress at admission, an urgent non-contrast CT chest was performed. Imaging was suggestive of a large anterior mediastinal mass with massive pericardial effusion and paraspinal involvement (figure $2 \mathrm{~A}-\mathrm{C}$ ). However, surprisingly, echocardiography revealed only mild pericardial effusion with clinicoradiological discordance. The following day, a repeat contrast-enhanced CT chest was performed as a prelude to CT-guided biopsy and to reconfirm the diagnosis (figure 2D-F). The repeat radiography showed a miraculous disappearance of the mediastinal mass. Bone marrow biopsy was subsequently

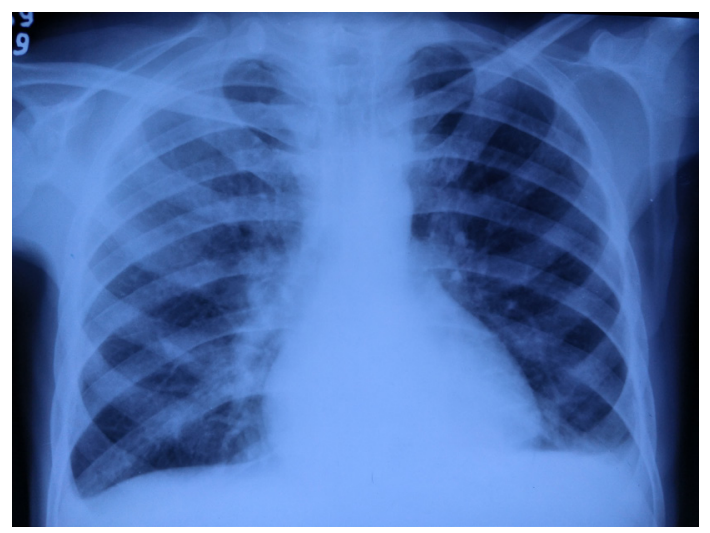

Figure 1 Chest X-ray, posteroanterior view, suggestive of cardiomegaly with bilateral pleural effusion (as evident by the blunting of the costophrenic angles).

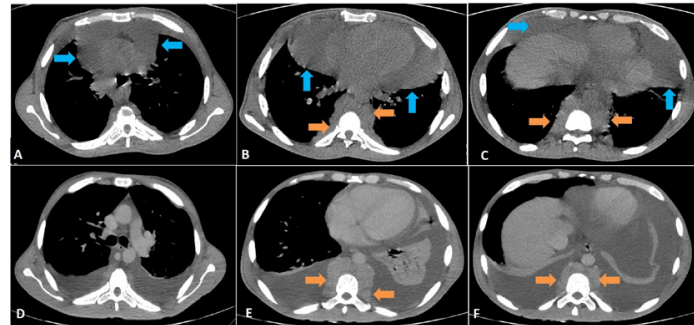

Figure $2(\mathrm{~A}-\mathrm{C})$ Non-contrast $\mathrm{CT}$ chest in a prone position revealed a large anterior mediastinal mass (blue arrows), massive pericardial effusion and paraspinal involvement (orange arrows). (D-F) Contrast-enhanced $\mathrm{CT}$ chest in a supine position revealed bilateral massive pleural effusion with a subjacent collapsed lung, discrete mediastinal lymphadenopathy and well-defined mass lesions in the bilateral paravertebral region along the dorsal aspect of thoracic vertebrae 8, suggestive of extramedullary haematopoiesis (orange arrows).

performed, revealing myelofibrosis with blast transformation (secondary acute myeloid leukaemia). He was managed with $7+3$ therapy and he finally succumbed to febrile neutropenia with secondary sepsis on day 24 of therapy. The disappearance of mediastinal mass overnight was, in fact, due to a change of position while performing CT scan from prone (on day 1) to supine (on day 2), which lead to the accumulation of pleural fluid around the mediastinum.

\section{Patient's perspective}

It is important to double-check the findings of an investigation before revealing it to the patient. Misinterpretation of the tests can add to the agony and cost of further evaluation for the affected family.

\section{Learning points}

- Preanalytical variables are an especially important part of the interpretation of the investigations.

- Do not interpret the images with prepresumed positioning of the patient and reaffirm the position of the patient, particularly when there is clinicoradiological discordance.

- CT scan can have different findings in supine and prone position. 
In both healthy and diseased patients, a thoracic CT is routinely done when the patient is lying in a supine position. ${ }^{1}$ When imaging is done in the supine position, lung collapse or atelectasis secondary to interstitial lung disease (ILD)/acute respiratory distress syndrome can result in distinct subpleural opacities, termed 'dependant densities', that can mimic fibrosis and obscure underlying structural abnormalities. ${ }^{2} 3$ Prone position typically reverses gravitational effects on lung blood flow and volume, improves visibility of the posterior part of the lung and resolves the 'dependant opacities', thus differentiating it from actual lung disease/opacities in patients with ILD. ${ }^{2} 3$ Thus, most radiologists or clinicians presume that the CT imaging is done in a supine position when not mentioned otherwise. In this case, imaging in prone position led to the accumulation of pleural fluid around the mediastinum due to gravitational effect and misled the clinician for a mediastinal mass/pericardial effusion, which disappeared on performing the imaging in supine position. Lack of attention to such preanalytical variables can mislead the haematologist and lead to unnecessary investigations or wrong clinical conclusions.
Acknowledgements We acknowledge the support of our Head of the Department, Dr Suman Kumar Pramanik, for helping in patient management.

Contributors All authors were actively involved in the management of the patient and have reviewed the manuscript. GS was the radiologist reporting the patient. $\mathrm{KM}, \mathrm{RB}$ and $\mathrm{UY}$ were clinicians in charge of the patient. RB and UY prepared the manuscript.

Funding The authors have not declared a specific grant for this research from any funding agency in the public, commercial or not-for-profit sectors.

Competing interests None declared.

Patient consent for publication Next of kin consent obtained.

Provenance and peer review Not commissioned; externally peer-reviewed.

ORCID iD

Uday Yanamandra http://orcid.org/0000-0002-0546-6585

\section{REFERENCES}

1 Verschakelen JA, Van fraeyenhoven L, Laureys G, et al. Differences in CT density between dependent and nondependent portions of the lung: influence of lung volume. AJR Am J Roentgenol 1993;161:713-7.

2 Volpe J, Storto ML, Lee K, et al. High-Resolution CT of the lung: determination of the usefulness of $C T$ scans obtained with the patient prone based on plain radiographic findings. AJR Am J Roentgenol 1997;169:369-74

3 Gotway MB, Freemer MM, King TE. Challenges in pulmonary fibrosis. 1: use of high resolution CT scanning of the lung for the evaluation of patients with idiopathic interstitial pneumonias. Thorax 2007;62:546-53.

Copyright 2020 BMJ Publishing Group. All rights reserved. For permission to reuse any of this content visit https://www.bmj.com/company/products-services/rights-and-licensing/permissions/

BMJ Case Report Fellows may re-use this article for personal use and teaching without any further permission.

Become a Fellow of BMJ Case Reports today and you can:

- Submit as many cases as you like

- Enjoy fast sympathetic peer review and rapid publication of accepted articles

- Access all the published articles

Re-use any of the published material for personal use and teaching without further permission

Customer Service

If you have any further queries about your subscription, please contact our customer services team on +44 (0) 2071111105 or via email at support@bmj.com.

Visit casereports.bmj.com for more articles like this and to become a Fellow 